\title{
Research on Virtual Practice Mode of Ideological and Political Theory Course in Universities
}

\author{
Luo $\mathrm{Bei}^{1}$ and $\mathrm{Yu} \mathrm{Tao}^{2,3, *}$ \\ ${ }^{1}$ Ideological and Political Theory Teaching and Research Department, \\ Southwest Medical University,Luzhou,Sichuan ,China 646000 \\ 36130831@qq.com \\ 2. Center for Studies of Education and Psychology of Minorities in Southwest University, \\ Chongqing,China \\ 3. School of Humanities and Management Sciences, Southwest Medical University, \\ Luzhou,Sichuan ,China 646000
}

The Project Supported by Sichuan Education Department

Corresponding Author:YuTao,E-mail:2286422429@qq.com

Keywords: Ideological and Political Theory Course; Network Virtual; Practice Mode

\begin{abstract}
The development of the Network information age has put forward new requirements to the traditional ideological and political theory teaching. The Network virtual practice teaching has become an important part of the ideological and political theory course and the future development trend. At present, we must follow the principle of setting up the bottom line, basing on the students' reality, focusing on the integration of online and offline interaction, actively explore construction sites, develop educational games and mobile APP, and innovate teaching content. Practice teaching is of great importance in the teaching of ideological and political theory courses in colleges and universities. The popularization of computer Network provides an opportunity for the reform of ideological and political practice teaching mode. With the help of Network technology, the platform and model of virtual practice teaching are established. For the students, Theoretical courses of social practice can enhance the effectiveness of ideological and political theory teaching has important significance.
\end{abstract}

\section{Theoretical Introduction of Network Ideological and Political Education}

Ideological and political education refers to the ideological and political education in accordance with the objective requirements of social development, on a predictable basis in science, through ideological and political education to make educated state of mind and behavior in a given period to achieve the desired results. Students' ideological and political education refers to education by Network-based or Network background, according to the objective requirements of social development and ideological and political education practical needs on a predictable basis in science, through ideological and political education to make educated state of mind and behavior habits in a given period to achieve the desired results.

Ideological and political education in the Network environment presents many new features. It should be noted that the said article refers to the new features from the target educational system, educational content to the form, method, carrier and the like in a Network environment more compatible, better play the advantages of the effectiveness of specific aspects. It showed the various elements of ideological and political education of new features and new trends in the development of the Network environment, in essence, represents the direction of the ideological and political education system of college students ${ }^{[1]}$.

Therefore, we must practice the current ideological and political education in the content and 
the methods used to set on the logical starting point, with the development of a dynamic point of view to study and grasp the new features. In general, the characteristics of ideological and political education under the Network environment includes: strong practical, technical, effectiveness issues outstanding. In this sense, ideological education forms, methods, means, ways and so depending on the material basis to achieve these means, methods, means, pathway. In the Internet era, Network technology is the most basic implementation of Network ideological education foundation and operation mechanism. Under the Network environment, factors that influence the effectiveness of ideological education is more complex and unpredictable variability and significantly enhanced.

\section{Basic Principles of Network Virtual Practice Teaching}

The Network virtual practice teaching is a virtual practice teaching activity under the Network situation. It is a virtual practice teaching activity which utilizes the space of the Network, creates the virtual scene through the virtual function, and carries on the object virtual education practice to achieve the teaching purpose and effect. In order to carry out the Network virtual practice teaching need to follow the basic principles ${ }^{[2]}$. Fig.1 shows the principle of Network virtual practice teaching.

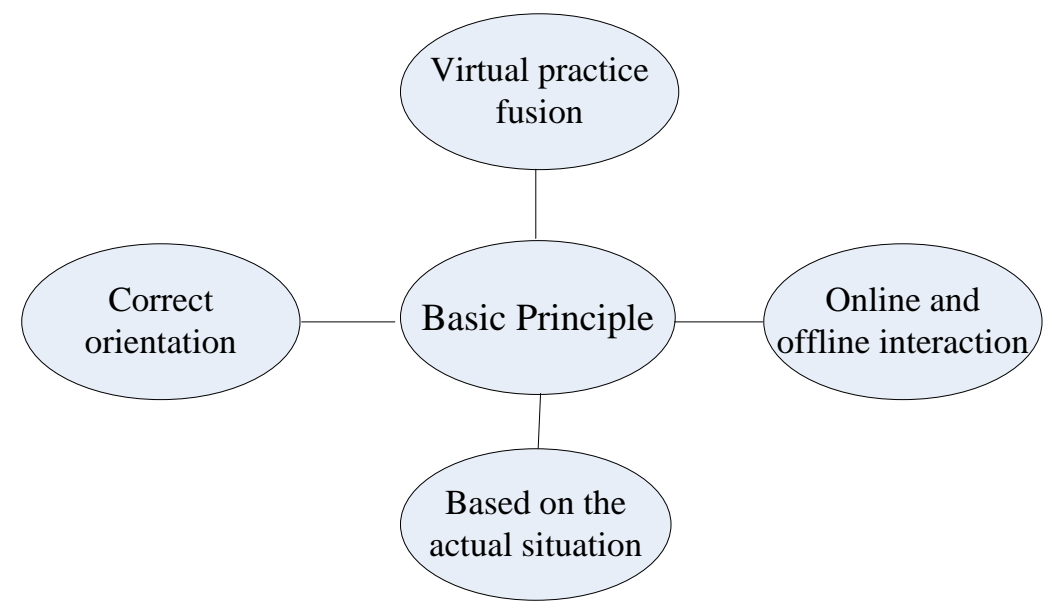

Fig. 1.The principle of Network virtual practice teaching

In the political direction, establish the bottom line consciousness, grasp the correct orientation. Ideological and political theory course is an important carrier and platform for college students to carry out Marxist theory education, and it is also the main channel and the main front of ideological and political education for college students. They are responsible for fostering the socialist qualified builders and reliable successors. In the starting point, comply with the demands of students, based on the actual students. Undergraduates are the main people contact and use Network media. They are influenced by the society and various thoughts, and they have distinct characteristics of the times. In the course of carrying out the Network virtual practice teaching of ideological and political theory course in colleges and universities, it is necessary to take these realities into account. Based on the students' actual situation, from the aspects of their teaching content design and virtual practice activities, Students meet the students 'reasonable demands, attract the students' attention, enhance the students 'acceptance and liking, and finally realize the teaching objectives of the ideological and political theory course through the students' favorite forms and activities.

In the specific implementation, we need achieve online and offline interaction, virtual practice integration. It is a form of ideological and political education to the students in the Network virtual environment, but the traditional practice teaching method still occupies the important position and plays an important role in the ideological and political theory course. In the actual teaching process, relying solely on the Network of virtual practice teaching can't fully achieve the purpose of teaching, so the specific implementation, we should focus on online and offline interactive integration, that is, Network virtual and traditional practice of organic integration. While carrying out the Network virtual practice teaching, we can combine it with the traditional practice teaching, the two have their own emphases, should play their respective advantages. Because only the 
combination of the two, online and offline interaction, in order to play the greatest force ${ }^{[3]}$.

\section{Construction of Virtual Practice Teaching Mode}

Ideological and political education content exhibit a wide range of features, its outstanding feature is the richness of ideological and political education content elements, the content of ideological and political education and the diversity of forms of ideological and political education content on its internal structure variability. Network is a large degree of freedom of information dissemination systems, all kinds of thoughts intertwined, surging against each other, a wide variety of information such as the surging tide of cross-border flows ${ }^{[4]}$.

Students' ideological and political education system refers to the elements associated with the Network Ideological and Political Education of a system consisting of interrelated whole. Therefore, when building the Network Ideological and Political Education System, should college students ideological and political education content combined with the Network. At the same time, the Network is no longer a reality in the body of the students, but to become the virtual body. Students subject to centric architecture, is at the center of the university student body Students Network Ideological and Political Education System, Network and put the contents of the status of ideological and political education subject students' Network ideological and political education system. In this architecture, the actual goal of the ideological and political education is the starting point and a Network of ideological and political education content system.

College student subject to centric architecture reflects the pertinence of ideological and political education. As a special group of college students, college students psychological characteristics that make them unstable factors in changing, the world, life and values is still in the formation stage. The main task of strengthening and improving ideological and political education, that education as the core ideals and beliefs, depth to establish a correct outlook on life and values education; focus on the patriotic education, advocating and cultivate the national spirit education; basic ethics-based, in-depth civic and moral education; to the comprehensive development of students as the goal, in-depth quality education. The four main tasks of the main provisions of the scientific content of the ideological and political education of college students revealed the body as the center of the ideological and political education content architecture.

\section{The Methods of Virtual Practical Teaching}

At present, the Network of virtual practice teaching of ideological and political theory course in colleges and universities is still at the initial stage, there are no more mature way and method. However, I believe that the Network of virtual practice teaching approach to explore the depth of integration of Network virtualization technology must be in the students' degree of love and acceptance of efforts, innovative ways and means ${ }^{[5]}$. Fig.2 shows the methods of virtual practical teaching.

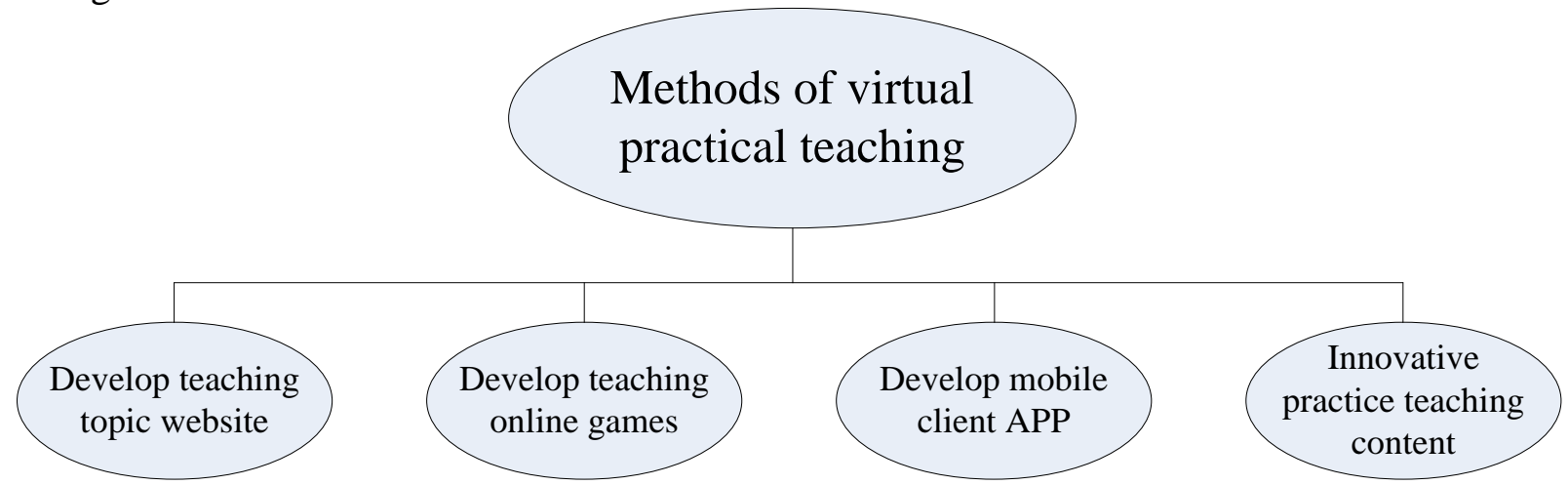

Fig. 2.The methods of virtual practical teaching

Construction of ideological and political theory teaching topic website. With the advent of the Network society and the ideological and political theory education and teaching situation of the continuous development of the urgency of building thematic sites gradually strengthened. Adhere to 
close to the actual students, pay attention to the practical needs of the principle, the real site into the ideological and political theory of teaching activities to carry out and evaluation of the intensive platform. In the functional realization of interactive, additional discussion and area to strengthen communication. Development of ideological and political theory teaching online game. Develop the ideological and political theory course teaching virtual games online, through the game to carry out teaching activities and teaching practice, this is a time to attract students to break the existing practice of teaching the new dilemma.

In recent years, the popularity of smart phones show a growing trend, college students are the main use of smart phones. In the development of mobile client APP, we should pay attention to practicality, so that the functional settings and ideological and political theory of the main content of the course, students are closely related to campus life; to enhance interaction, so life and death, between teachers and students through mobile phone customers end APP real-time communication. The innovation of Network virtual practice teaching content mainly refers to the process of teaching, some focus on increasing the number of online visits, Network collection of teaching, Network social research and discussion of Network realities and other activities. When the Network collects the discussion of teaching or Network real problem, teachers need to choose the corresponding topic or case purposefully, and then analyze the concrete principle of corresponding course of ideological and political theory course.

\section{Conclusions}

The popularization of the Network and the extensive application of the computer have brought new development opportunities to the practical teaching mode of the ideological and political theory course in colleges and universities and put forward the severe challenge. Network virtual practice teaching is a new attempt in the teaching reform of ideological and political theory course in colleges and universities. Compared with the traditional classroom teaching and practice teaching, it has obvious advantages and progressive significance. Fully utilize the Network carrier, construct the virtual practice teaching mode, and carry out the virtual practice teaching, which provides a new way and platform for strengthening and improving the ideological and political theory teaching in colleges and universities. Network virtual practice teaching and traditional practice teaching is not a departure from, but the organic connection, interactive influence, in order to achieve ideological and political theory teaching objectives and play a role. The virtual practice mode greatly improves the carrying capacity of the practical teaching of ideological and political theory courses in colleges and universities and brings new teaching ideas and teaching models for ideological and political theory courses.

\section{References}

[1] Zhang guan Lu, Construction of Ideological and Political Education under self-education mechanism [J] Ideological and Political Education, 201022 (3) 1-380-81.

[2] Ai Si lin. New System of Ideological and Political Theory Course and Teacher Development [M] Beijing: Tsinghua University Press, 2008.2, 302-303,194.

[3] SUN Wei-ping. On the Philosophical Implications of Virtual Practice [J]. Teaching and Research, 2010, (9).

[4] CHEN Bao, Liu Hui-qiang. Discussion on Virtual Practice Teaching of Ideological and Political Theory Course in Universities [J] .Teaching Course, 2013, (8).

[5] Zhao Lanxiang, Mei Ling. Ideological and Political Theory Course Practical Teaching and Research Network [J]. Agricultural University of Hebei (Agriculture and Forestry Education Edition), 2013, (2). 